Available online at www.jmle.org

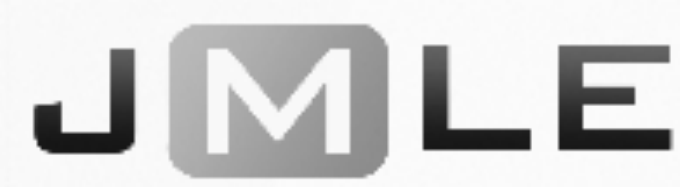

The National Association for Media Literacy Education's Journal of Media Literacy Education 10 (3), 152 - 170

\title{
VOICES IN THE FIELD \\ Mediating Religious Literacy among Primary School Children in Gujarat: Classroom as a Liminal Space
}

\author{
Kiran Vinod Bhatia \\ $M I C A$, India
}

\begin{abstract}
Articulation of religious guidelines in the political milieu never takes place in a disembodied form; rather politically inscribed religious discourses are embedded within and conveyed through specific institutional channels, including media organizations and education institutions. My experiences of working as a media educator in villages in Gujarat have helped me understand how the learning of such discriminatory practices begin early as students use various linguistic and socio-cultural cues in order to make sense of the society. In this paper, I use critical media literacy as a way to redefine classroom as a liminal space and create conditions for emergence of an alterity. Critical media literacy (CML) can provide young students with the skills required to upend the dominant discourse of religious violence, to create new narratives from the interstices- from the in-between, and pendulate between the fixed identities subsumed in binaries such as self-other, victim-perpetrator, us-them, and most importantly Hindus-Muslims. In this paper, I attempt to answer two research questions. First, how is this dominant rationality of religious hatred perpetuated through media texts and the socialization process in schools? How does it influence the everyday experiences of young students in two villages in the Sanand tehsil of Ahmedabad district in Gujarat? Second, how can the classrooms be designed as spatial sites to encourage young students to counter their feelings of individualized prejudice and enact resistance? I illustrate how media educators can use CML to design classrooms as a liminal space and help students operate from the margins of the socialization they receive and thus be more open to different regimes of truth practiced in different religious communities.
\end{abstract}

Keywords: critical media eduction, media bias, religious discrimination, youth studies, liminal classroom, spatial reorientation, critical participation

The study of the political topography of Gujarat grants this state an interesting conceptual status in the area of governance and citizenry. It is situated within two distinct political realms; the normative milieu of theory and the empirical description of 
lived realities (Jayal, 2001). According to the normative theoretical realm, the state is based on the constitutional ideas of liberal democracy and secularism which allow all citizens equal access to economic, social and political resources of the country. On the other hand, however, there is a world of lived realities, the descriptive-empirical realm, which witnesses the continued marginalization of various communities based on religious, linguistic, cultural and economic differences in the society. This distancing between ideals of secular equality and lived experiences of intolerance and violence against the "other" is identified as the leitmotif in this study of the contemporary political landscape of the state. Since the late twentieth century, this "other" is increasingly defined as a religious body, a corporeal being with well-articulated religious identity and as a site for imposing discipline and control in order to gain political, social and other advantages (Bhatia, 2017; Nussbaum, 2008; Sud, 2012; Yagnik and Sheth, 2005).

In this paper, I attempt to answer two research questions. First, how this dominant rationality of religious hatred is perpetuated through media texts and socialization in schools (Bhatia, 2017; Rajagopal, 2001); and how it influences the everyday experiences of young students in two villages in the Sanand tehsil of Ahmedabad district in Gujarat. Second, how can classrooms be designed as spatial sites to encourage young students to counter their feelings of individualized prejudice and enact resistance. I identify critical media literacy (CML) as an approach through which young students can be equipped with critical competencies required to upend the dominant discourse of religious discrimination, to create new narratives from the interstices- from the in-between, and to pendulate between the fixed identities subsumed in binaries such as self-other, victim-perpetrator, us-them and most importantly Hindus-Muslims (Bhatia, 2017). For this, it is crucial that young students enjoy the creative liberty to enter a structureless realm and critically analyse their social identities and lived experiences. This implies that classrooms must be designed as liminal spaces where young students use the boundaries between the naturalized categories of Hindus-Muslims as a vantage point to question the neutrality of information with regard to religious identities/groups and render them problematic. In this paper, therefore, I illustrate how media educators can use CML to design classrooms as a liminal space and help students operate from the margins of the socialization they receive and thus be more open to different "regimes of truth" (Foucault, 1997) practiced in different religious communities. In this paper, I show how the everyday experiences of young students in two villages of Sanand Tehsil of Gujarat are implicated in religious politics and sectarian identities which are perpetuated by both media texts and schools.

\section{CONTEXT AND BACKGROUND}

The two villages ${ }^{1}$ selected for this work are situated in the Sanand Tehsil of Ahmedabad district and collectively have a population of 6,800 registered voters. I

\footnotetext{
${ }^{1}$ I have not revealed the names of these villages to ensure that the residents, especially students, are not subjected to any form of untoward attention.
} 
have been working as a media educator at the Gram Prathmik Shala, the only municipal school in these villages, for 31 months now.

Having acquired the required permission from the Jilla Panchayat to teach primary school students i.e. grades 6,7 and 8 , I started conducting 40 minutes long media education sessions at the school three times a week. I have conducted participant and non-participant observations, created field notes, and conducted interviews with students while media education modules for promoting religious literacy were being developed, implemented, and evaluated.

My interactions with students helped me understand how they are socialized by media narratives that limit their interpretations about the world within the binaries such as self/other and Hindu/Muslims (Bhatia, 2017; Bhatia \& Pathak-Shelat, 2017), how they are exposed to a pro-Hindutva rhetoric prevalent in regional media channels wherein Muslims are demonized (Ahmed, 2010; Jain, 2010; Rajagopal, 2001), and how they are educated in schools which reinforce these differences, promote ideas of purity (Sikand, 2007; Sud, 2009) and fail to foster critical thinking (Nussbaum, 2008).

I used ethnographic methods including non/participant observation and semistructured interviews to analyze how the ideology of religious discrimination is perpetuated in and through their communication ecologies. This helped me analyze how students were religio-politically socialized, thus enabling me to identify ways to use CML as a pedagogic strategy to design classrooms as liminal spaces. I implemented the CML exercises designed to promote religious literacy in classrooms and worked with 114 students from three grades i.e. 45 students from grade eight, 31 students from grade seven, and 38 students from grade six. After the CML exercises were implemented, I conducted semi-structured interviews with 49 student participants to evaluate the efficacy of the exercises designed. In this paper, I present these CML exercises to help other educators develop innovative pedagogic interventions to challenge the ideology of discrimination prevailing among students in classrooms across a variety of socio-political and cultural context.

\section{KEY THEMES}

In what follows, I explicate the role of media and school in reinforcing a discriminatory ideology based on religious identities through acts of micro-aggression among young students.

\section{Regional Media and the Rhetoric of Discrimination}

According to many scholars (Ahmed, 2010, Jain, 2010; Rajagopal, 2001), regional language media supports the Hindu political maneuvers for power and justifies the desire to discriminate against individuals based on their religious identities. Most of these news channels and papers have been reprimanded by the Press Council of India on account of publishing stories intended to stir up communal passion. With regard to the coverage of communal riots in Godhra in 2002, for instance, Justice K. Jayachandra Reddy, the then Chairman of the Press Council of India, condemned regional media for its use of inflammatory language, especially the coverage by newspapers such as Sandesh and Gujarat Samachar. He noted with anguish that ". . . a large number of 
newspapers and news channels in the country and, in particular a large section of the print and electronic media in Gujarat have, instead of alleviating communal unrest, played an ignoble role in inciting communal passions leading to large scale rioting, arson and pillage in the state concerned."

These regional media channels often circulate biased news supporting the Hindutva ideology and this has increased the presence of religion in public spaces and consequently the public mind (Kumar, 2010; Farouqui, 2009; Karim, 2009). According to Bhatia (2017), regional media in these villages don't engage in direct aggression against a religious community. Instead, media adopt subtle modes to reinforce the dominant discourse and often fall short of raising questions about thought and power. Many scholars (Bennet, 2008; Buckingham, 2003; Willet, 2008; Hoechsmann \& Poyntz, 2012) suggest that media play a central role in the socialization, acculturation, and intellectual formation of people, especially young individuals.

Often times, these media narratives are supported by peer circles, families, communities, societies/culture, and educational institutions in which young students learn and grow (Kononova, Alhabash, Cropps, 2011). Media also help to build subcultural and inter-generational solidarity or conflict through imagination, information, fun and pleasure (Banaji, 2006; Buckingham and Bragg, 2004; Johnson, 2001; Khan, 2014). When young students consume these narratives in absence of the required critical skills they start practising these discriminatory ideas in and through their everyday interactions in relation to other students in the classroom.

Let us take the example of Lokesh, a class eight student who regularly reads Gujarat Samachar. During one CML session, we were discussing the role of media in pacifying people during times of crisis. As I kept referring to the unbiased reportage during communal riots by The Indian Express- an English language newspaper, he was offended and after the class he approached me and explained:

Most of us follow regional newspapers because they don't mince their words to appeal to a particular intellectual class. Sandesh reports things as they are; if Muslims commit terrorist activities, they must be criticized and punished. They initiated the Godhra riots after all. They burnt the carriage.

Lokesh not only relies on regional media to procure information to nourish his world view but he also uses social media, especially Whatsapp, to circulate messages which are discriminatory and can be identified as anti-Muslims. Let us look at a message he sent to his Hindu friends, including me, just a day before the Muslim festival of Bakri Eid, also known as Eid al-Adha also called the "Festival of Sacrifice."

Figure 1 shows the message is drafted in Hindi and reads: 
What kind of festival is this where people show affection for each other while they slaughter animals?

\section{Figure 1 Bakri Eid}

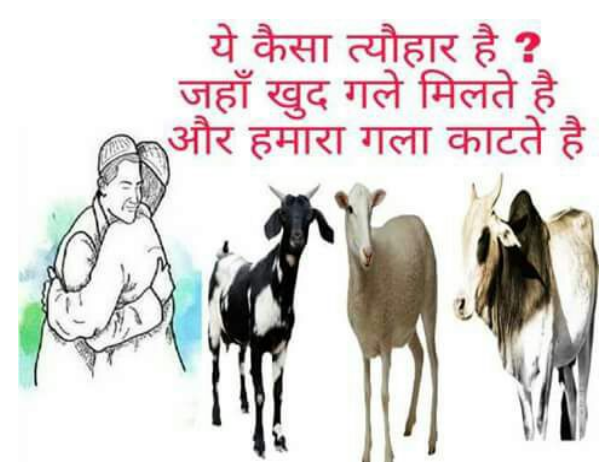

Such discriminatory practices enacted young students in these villages are reinforced by regional media narratives which categorize individuals into neat compartments such as acceptable/unacceptable, good/evil, right/wrong and so on based on their religious identities. Many articles in newspapers including Gujarat Samachar, Sandesh and Divya Bhaskar were published to condemn this practice of slaughtering animals during the festival of Eid. Figure 2 shows an article published by Gujarat Samachar on August 31, 2017. It reads, "On this Bakri Eid, sacrifice your bad habits instead of your animals."

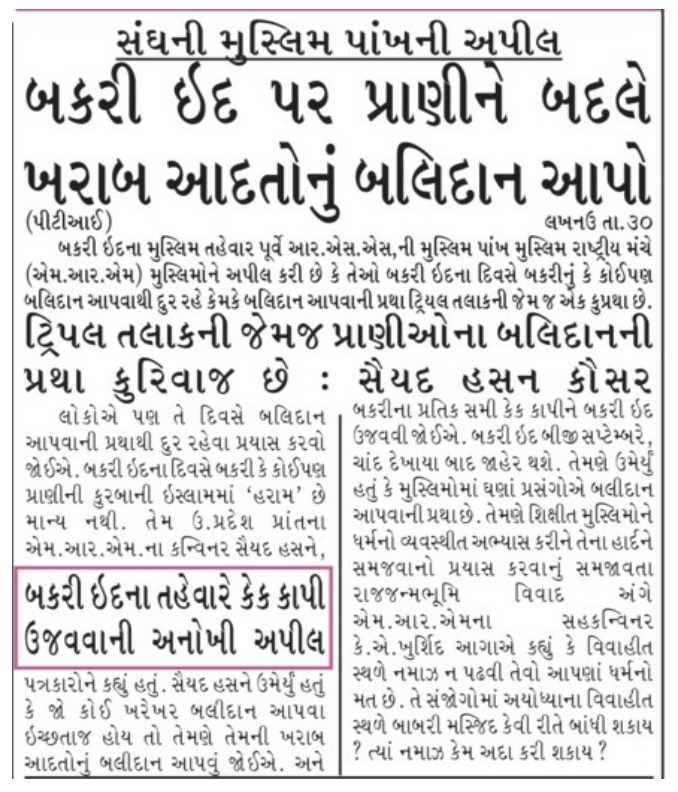

\section{Figure 2}

Newspaper Article Condemns Eid Festival

These local dailies constitute the largest market share and have the highest media readership in Gujarat (Sonwalkar, 2006). Like Lokesh, most students in the 
villages read these newspapers and feel either powerful or alienated. The regional media define ways in which the religious other is perceived, providing interpretive frames that resonate across social space (Bhatia \& Pathak-Shelat, 2017; Rajagopal, 2001). Through repetitive explanations, evaluations, and assumptions, they juxtapose unrelated ideas to create a dominant narrative. This reinforces stereotypes about the other, creating fear and a sense of aversion towards things, people and practices that challenge their monolithic picture of reality.

Regional media, thus, is a field implicated in prejudice and bias and can reinforce prevailing rationalities by utilizing the discursive potential of representations. Such media representations have profoundly marked the political landscape and the collective psyche of young students in these villages in Gujarat.

In this context, schools and classrooms act as fertile sites where students engage in these practices of religious discrimination, form bonds based on religious affiliations, engage in practices of micro aggression and strengthen their peer relations within their respective communities.

The regulatory power of religion also operates through educational institutions that work as material sites for constituting the collective psyche of students and generating a dominant frame for interpreting social realities in Gujarat. In particular, the unapologetic reliance on rote-learning and a banking system of education in which power hierarchies are reified and an uncritical submission to authority is considered to be a virtue, serves to reinforce dominant political rationalities. From a young age, students are taught to be subservient, obedient and unquestioning. Education is used in this way as means to indoctrinate young minds with a single narrative, a single truth and a fear of power structures. According to Nussbaum (2008):

Through primary and secondary education, young citizens form, at a crucial age, habits of mind that will be with them all through their lives. They learn to ask questions or not to ask them; to take what they hear at face value or to probe more deeply; to imagine the situation of a person different from themselves or to see such a person as a looming threat to their own projects; to think of themselves as members of homogenous groups or as citizens of a nation, all of whom deserve respect and understanding. It is therefore not surprising that education plays a large part in India's recent political struggle.

Very recently, for instance, various right wing Hindu political parties in Gujarat, including the Rashtriya Swayamsevak Sangh (RSS), Vishwa Hindu Parishad (VHP) and Bajarang Dal have fought aggressive campaigns and promoted public action in support of inclusion of a discriminatory ideology in school textbooks and educational institutions. Similarly, various Muslim political leaders use educational institutions to encourage young citizens to embrace the Islamization of education as a counter narrative to the Hindu rhetoric in public schools (Fahimudin, 2009; Aleaz, 2005; Bandyopadhyay, 2002).

The madrasas are trying hard to maintain their perceived religious identity and often fail to provide formal education that the students need (Bandyopadhyay, 2002). 
Some of these madrasas “... thrive on perpetuating sectarian identities which increases political and ideological polarization directed against dissenters in Islam and also nonMuslims" (Ahmed, 2010). The consequences are serious - the imprisonment of students within a single correct ideology, curtailment of freedom, and an educational environment based on fear and hatred. We must identify the invisible lines sketched by these orthodox religious experiences of students in their communities that are intensified at schools and at play.

For instance, in the Gram Prathmik Shala, Hindu and Muslim students sit separately i.e. in different rows, and teachers and school authorities encourage this practice. Hindu students sit in the first four rows whereas Muslim students sit in the last four rows. These young students often perpetuate discrimination at school against their classmates through acts of micro-aggression like name calling, fighting, forming play teams based on religious affiliations and sometimes alienating students from a different community from participating in their group activities. They refuse to work together and always form play/work teams based on their religious identities. They seldom share their food or eat from the same plate. Also, young students don't inhabit the same community spaces in the village areas. The residence of Hindus and Muslims are in different areas of the villages and are situated around a place of worship. Conversations, routines, cultural practices and places of play are divided by these invisible spatial lines, its manifestation observable in their classroom interactions.

Many scholars such as Giroux (1992), McLaren (1995), and Lankshear (1997), however, have drawn inspiration from the critical thought of Freire and Foucault and identified classrooms as sites for the construction of transformative cultural, moral and political identities. They emphasize that within classrooms, educators can help students challenge the ritual inscriptions of the imposed religious/political identities and design interventions to create a fraying around the edges of the naturalized relations of power. For this to happen, classrooms must act as contact zones- a site where disparate cultures, identities, ideologies, and experiences meet without the restraining force of the normalized structural limits imposed by authorities (Conroy, 2004; Pratt, 1992). In other words, a classroom should exist as a liminal space which lies beyond the takenfor-granted normality of everyday experiences wherein there is a reformulation of the learner's meaning frame (Schwartzman, 2010) and a friction is created in the learner's subjectivity.

Many studies have successfully deployed the theory of liminality to reimagine classrooms and education as fluid sites which allow students to question their subjectivity and replenish it with new perspectives and learnings. For instance, Meyer and Land (2005) used the theory of liminality to create conceptual getaways in classroom teaching which helped their students perform a progressive function by encountering and integrating something new to their already existing understanding. This involves "... envisaging of an alternate version of the self which is contemplated through the threshold space" (Land, Rattray \& Vivian, 2014).

Similarly, Conroy and Rutyer (2008) conducted a study to explicate how liminal education can be used to counter the naturalized power structures in the context of a capitalist/consumer driven education system. According to them, creating a liminal space involves infusing classrooms with intended moments of creativity and fluidity 
which disclose alternative positions of being and equip young students with critical reflective dispositions to adopt and occupy these positions of 'otherness'. Taking this argument ahead, Alison Cook-Sather (2010), provides empirical insights into how classroom as a liminal space can democratize the student-teacher relationship and give rise to reciprocal learning and teaching. Many scholars (Hurlock, et. al., 2008; CookSather \& Zanny Alter, 2011; Irving \& Young, 2004; Lynn, Kawalilak \& Patterson, 2008), therefore, contend that the theory of liminality can provide a conceptual framework for analyzing the new subjectivities and meanings which can emerge when students and teachers occupy margins, share the uncertainty associated with exploring and examining human emotions in the context of education and learning.

In order to create such liminal classroom experiences for young students in these villages, I used the CML approach to conceptualize an ontological space and an epistemological position where the codes of religious status and power structures do not apply. In the following section, I delineate how CML provides the required tools and strategies to reconceptualize classroom as a new threshold and a liminal space created to help young students explore alternate realities.

\section{Using CML to Reinvigorate Classrooms as Liminal Spaces}

Critical media literacy (CML) is premised on the task of problematizing the given. According to Poyntz and Hoeschsmann (2012), CML takes “... what may appear natural in a media-saturated environment and challenges the learners to see through the facets of media that may have been uncritically absorbed." CML is a process which allows students to distance themselves from their immediate knowledge structures, community networks and media circles in order to revisit the truths invested with the existence of a normalized stable society. In other words, it draws attention on how these truths and realities operate through a set of formative technologies, texts, practices and institutions while at the same time demystifying the conditions which lead to the creation of those texts and the subsequent emergence of a dominant rationality. CML exercises must move students into a 'transitional realm' so that new experiences can delimit the normative categories of identification arbitrarily imposed by the structures of power.

This liminal space is not merely a spatial site constituted by the presence of certain attributes; rather it is a space that is created through a temporary suspension of primary identities. Using CML to initiate students to critically analyze their lived experiences requires creating a liminal classroom which may be regarded as "... Nay to all positive structural assertions ... a realm of pure possibility whence novel configurations of ideas and relations may arise" (Turner, 1964). This process of creating a space (different from the everyday experiences of students) becomes very crucial if students are raised in a discriminatory ideology which encourages them to perpetuate prejudices, biases and a violent behaviour (Ranieri \& Fabbro, 2016).

In this paper, I identify two core CML principles which help allows students certain freedom and discretion to juggle with their prevailing conditions of existence, the taken-for granted realities of religious identities and how they play out in everyday interactions (Turner, 1966). According to UNESCO (2016), critical civic engagement should be an integral component of all CML exercises. With regard to religious 
literacy, this component is articulated in and through the practice of two core principles namely fostering critical empathy and exploring alternate realities. I will now describe the CML exercises I developed to design classrooms as a liminal space where students could exercise and engage with these ideas.

\section{Fostering Critical Empathy}

Critical empathy involves taking into consideration the 'other's' perspective, entering a different realm of reality and examining situations of discrimination from within the felt contours of the lived experiences of others (Valsamidis, 2014). CML can be used to instill this value among students by positively reorienting Hindu-Muslim students towards each other, thus, creating a culture of care in the classroom.

I asked my students to create texts (Bazalgette, 2009) about the 'other', based on their limited interactions with members of a different religious community. They were allowed to use any medium of their choice and draft a narrative. Most of the narratives I received reflected a limited, often biased, understanding of the other. Some of the major themes that emerged from these narratives are shown in Table 1.

\section{Table 1}

\section{Narratives of the Other}

\begin{tabular}{|l|l|}
\hline Narratives Submitted by Hindu Students & Narratives Submitted by Muslim Students \\
\hline Muslims slaughter animals, especially cows & $\begin{array}{l}\text { Hindu gods are false; they worship many } \\
\text { different gods }\end{array}$ \\
\hline Muslims are violent & $\begin{array}{l}\text { Hindus are not friendly; they dislike our food } \\
\text { habits }\end{array}$ \\
\hline Muslims are less educated and less competent & Hindus are against Muslims \\
\hline Muslims cannot be trusted & Hindus want to destroy the Muslim culture \\
\hline $\begin{array}{l}\text { Muslims spend most of their time reading } \\
\text { Quran and reciting Namaaz }\end{array}$ & $\begin{array}{l}\text { Hindus are a misled group, blindly following } \\
\text { the western culture }\end{array}$ \\
\hline
\end{tabular}

After they had submitted their first narrative, I paired them with students from the other community and asked them to submit a "team narrative" which took into account the concerns of both team members. When they started working as teams in the classroom, this exercise reoriented them both physically and mentally towards each other; at least temporarily. They had to sit with their teammate and share the work space. They had to exchange ideas, engage in conversations, and identify themselves first as teammates and later as religious subjects.

Students were able to acquire a "liminal personae" as members of a temporary community of classmates. This new identity is articulated through team norms created by the members, often based on the dissolution and undoing of normative categories. When Hindus and Muslim students worked together they agreed to borrow from 
diverse knowledge structures and present a more comprehensive analysis. They were more attentive to the experiences of the 'other'; listening to stories emerging from a different community was not only fascinating for them but also helped them feel a lot closer to the realities of the 'other.'

Muslim students rectified some false representations of their community in these narratives as they introduced the Hindu students to their lifestyle choices. According to Najma, for instance, many Muslims opposed the beef ban because cow meat was very cheap and an easily available source of nutrition for them. Similarly, many Hindu students suggested that food consumption choices were more than just religious practices and must be respected. This was possible because the team members decided to use dialogic practices of deliberation to present their ideas and often engaged in constructive discussions asking relevant questions and offering useful insights. When they worked as teammates they were eager to explore different "lifeworlds" and learnt to effectively mull over these difference.

As is evident, critical empathy can engender a culture of care where students develop interpersonal relations with others based on personal experiences in a healthy and safe classroom space. This CML exercise helped me use pedagogic techniques such as critical deliberation, classroom discussions and content creation in order to defamiliarize the primary socialization (Berger \& Luckmann, 1996) my students receive through various communication channels and social actors including their parents, teachers, friends and other village residents. When my students inhabit the mediascape, critically analyzing narratives, creating new stories and producing content, they are "betwixts and between" the positions assigned and arrayed by social categories such as customs, rituals, law and conventions (Turner, 1964). CML allows for learning to occur in the "temporary project teams" (Tempest \& Starkey, 2004) which are created as they learn to use and operate different kinds of media such as the mobile phones, cameras, voice recorder, and so on. My students are excited to handle these media technologies, to learn media skills and to gain access to a mobile phone, if only for a while (Banaji, 2015; Harvey, 2003). This in a way turns out to be a strong contributing factor in bringing them together and encouraging them to work as a team in which they care about and support each other.

This culture of care and critical empathy can be translated into healthy narratives and insightful representations created to challenge the mainstream/dominant media texts that are based on ideas of prejudice and hatred. Through the CML exercise discussed in the following section I helped my students generate locally situated content which will help them and their community members to reimagine their villages and the residents from within a critical frame of interpretation.

\section{Exploring Alternate Realities Through a Photowalk}

As discussed earlier, houses in the villages are planned based on religious identities of the families. The residence of Hindus and Muslims are in different areas of the villages and are built around a place of worship. In the case of the Muslim residential areas i.e. Moto-Nano Momin Nivas, the mosque is the centre around which the houses have been constructed. In the same way, Hindu houses are concentrated around the Ram temple near the 'Bhagor', one of the village gates. 
Such a spatial arrangement reflects of a system of governance that privileges religious identity over other facets of citizenship (Sud, 2010). Also, regional media's representations of spaces that Muslims and Hindus can occupy have strengthened a sense of suspicion among residents of Gujarat. There have been many instances where Muslims are either not allowed to own property in Hindu dominated areas or where Hindus refuse to rent their houses to Muslim tenants.

The regional media reinforces these segregations by identifying spaces based on the cultural markers they carry i.e. a mosque, women in burkhas, the sound of the azaan, men wearing namaaz caps and so on (Kirmani, 2008). An ethnographic study conducted by Froystand (2005) of upper caste Hindus in Kanpur demonstrated a complex relationship between national level discourses in media and the emergence of religious and caste boundaries in everyday life through the regulation of spaces. What we witness are invisible lines of spatial limitations for the two religious communities and acts of micro-aggression in public spaces such as offices, schools, public transport, and local markets. The ghettoization of Muslim communities on the margins of Ahmedabad in Gujarat (Berman, 2003) is a glaring example of how spaces are regulated based on religious identities.

These young students learn from their elders in the village where Muslim and Hindu households are built in separate lanes. Several invisible lines have segregated young students and their communities into different groups with non-fluid boundaries. CML activities helped me encourage my students to enter a space of fluidity and use media technologies to work on a project to create narratives from and of these divided village spaces together.

Groups of 5-6 students from both the communities were created using a lottery method and I decided to take a photowalk with them. This was done to counter the media narratives they were familiar with, narrative which constructed the character of a space (safe/unsafe, open/closed, liberal/regressive) based on the religious community which occupies it. When my students took a walk through these familiar village lanes, using a camera granted them an authorial role, a liberated position which they had never experienced. Also, working together as team-mates created an ambiguous situation, a novel experience which contradicted the structured narrative of the media and the community and brought them close to a seclusion site (Tuner, 1983). In this seclusion site, young students have a physical reality i.e. taking walks together, working on projects and engaging with each other, but lack the social reality which limits their physical interactions i.e. they are no more members of a religious community but teammates working for rewards, prizes and grade points.

Based on the photos taken during these walks, we created photo stories of these spaces using the techniques of cultural mapping which allowed students to combine "the dialectics of practice and analysis" (Buckingham, 2003). In other words, CML was employed as a site to disturb the permanent and pre-determined visibility in these spaces that regulate the behavior of members. Students created counter-maps i.e. a technique within the field of cultural mapping, to challenge the village's formal description of these spaces by appropriate, effective, and official techniques of representation to create a different narrative. For instance, one team consisting of five students created a photo novel wherein each photo in some way or the other reflected 
how members of one community could and were using the spaces informally designated for the exclusive use by the other community.

In one such photo, a Muslim student was seen hanging on the roots of a huge Banyan tree which is situated in the middle of the Hindu dominated area. This tree is revered and worshipped by Hindu residents and Muslim students often avoid playing in and around this area. When they were encouraged to think of ways in which they could insert the existence of these spaces with a different truth, a new experience and new conditions of possibility, they adopted different media technologies and modes of conduct to use these same spaces as cultural sites for resistive practices. These alternate representations of spaces and sites were presented to the village community and were well received. Today students from the school often frequent these spaces together, use them as sites for their media production activities and seek each other's help to quell possible tensions.

During the conceptualization and implementation of these CML exercises, there were various facets of the student-teacher relationship which couldn't be restricted within the frame of a disinterested sociological inquiry. It was important to account for the emotions we went through as we engaged with social issues which threatened my students and their position in the society. Discussing the role of the media educator, therefore, becomes very important in order to create a liminal space wherein students learn to critically engage with cultural diversity. In this situation, a media educator acts like a leader who binds the "neophytes" together in a community of new experiences and learning outcomes (Conroy, 2004).

My role as a media educator helped me create learning conditions in order to distance my students from the established network of connections which influence their interactions in the cultural spaces of the village. It was a challenging experience because some students felt a sense of dejection; they were offended when I compelled them to work together if they wanted to learn how to use the camera and the laptop. This often created an ethical conflict within me- Was I allowing my students to exercise their choice? Was I allowing them to believe in truth claims they had put their faith in? Was I subjecting them to some unintended harm by encouraging them to enact practices of resistance by working with students from the 'other' religious community? In the following section I provide ideas to resolve these conflicts based on personal experiences.

\section{Media Educator as Trickster}

Media educators, I believe, must begin with reflecting on their privileges and what authority these grant them in a classroom environment. Identifying my privileges helped me understand my strengths, dwell on my expertise and co-create learning experiences with my students to aid their critical thinking abilities. For instance, access to new media technologies such as a mobile phone was a privilege I enjoyed. When I decided to use this privilege to provide access to my students, they started appreciating me. There is no denying that when students start to adore you they will try to please you by expressing ideas they think will make you happy. This is where identifying your privileges will help you distinguish if students are expressing ideas to give voice to genuine concerns they face or are they simply trying to gain your approval. I have been 
working with these students since 2015; by now they know me only too well to be able to fool me in case they wish to feign interest in classroom activities. A media educator must constantly strive to create strangers out of these well-meaning familiar faces and push them outside the known realities.

In other words, a media educator is a trickster (Conroy, 2004) who operates within the dualistic framework of "familiarity-strangeness" (Gennep, 1960). I begin this self-chosen journey of entering a transitional stage by accepting that I am not a member of the community and that we might find it difficult to understand each other. I tell my students that I don't always relate with them and occupy a position on the margins. When my students realize that I come from a different society they are more open to accepting the differences. Note a fragment of a conversation I had with a few eighth grade students during a photowalk:

Muskaan: Ma'am, why-- do you wear a cross around your neck? Aren't you a Hindu?

Gopal: Ma'am is from the city. She can do as she likes. People have more freedom in the cities. Effects of modernization, you see...

Ma'am: I stay 5 minutes from your village. . My college is in the village. I wear a cross because I identify with Christ who was described as a political revolutionary in many books I have read.

Muskaan: Still . . . you are an outsider. . . (trailing off) What if I don't want to wear a hijab after marriage? That will be so odd. . . (starts giggling)

Komal: They won't allow! You will have to get wear a hijab. . . (everyone starts giggling) and ma'am will attend your wedding. . . (Laughter grows louder)

Ma'am: Well, you may try asking your parents to allow you to skip wearing the hijab sometimes. It is not that difficult; why don't you have a conversation with them?

Rihana and Nausreen: (Giggling) . . . we can ask; only if we wish to move around without it! It is awkward for us! Hahahah!

In this context, my role as a media educator helps me stay on the margins, acting as an outsider and an insider simultaneously. I present myself as a role model they would aspire to follow if conditions are favorable, an outsider they look up to. Also, this very outsider enters their immediate environment to allow them to think of alternate notions of conduct as I present them with a new learning environment which they have never been a part of. As an insider I encourage them to rethink about their discriminatory behaviour towards the 'other'; simultaneously, I use my position as an outsider with 
privileges to grant them access to inclusive media narratives and compel them to think with me from the margins.

This is what a trickster does: we induce friction in the taken-for-granted social structures without necessarily disrupting authority (Velde, 2012). For instance, people in these two villages still rely on the axiomatic values of the society embedded in strictly defined power-distance between the teacher and the student and so a media educator can be identified as the "personification of the self-evident authority of tradition" (Turner, 1964), who possesses certain powers by the virtue of being a teacher and exerts control over the class. I use this position of power to introduce new elements in the student-teacher relationship and rebuild the classroom based on a dialogic pedagogy.

Students are encouraged to ask questions, engage in dialogues and follow a discussion based model during classroom interactions. I perform cultural tasks working as a media educator and assume a didactic role by helping students form new communities in which they share a common bond as teammates under the leadership of the trickster and forge strange realities with a sense of curiosity. I use critical media education to enable the formation of a "communitas" in which students move away from their immediate community to something larger and freer.

For instance, I use media production activities as a theoretical realm to produce a learning experience in which the authorial role is shared by students from both the communities in the absence of a familiar script, thus, encouraging them to speak as unique individuals and not a members of a religious community (Buckingham, 1995; Gennep, 1960; Goodman, 2003; Haydari \& Kara, 2015; Poyntz \& Hoechsmann, 2012; Rantal, 2009).

During these media production activities I ensure that all the students participate in the meaning-making process. This requires of the media educator to control students who suppress others, prevent the dominant social identities such as majority-minority and Hindu-Muslim from influencing the intragroup and intergroup interactions and constantly motivate students to follow a common goal, a common purpose and a collective task. When these classroom dynamics are to be managed, the trickster must always try to create ". . . a community or comity of comrades and not a structure of hierarchically arrayed positions" (Turner, 1964). In this liminal situation, the media educator must bear the burden of allowing students to act out of their institutional roles i.e. suspend their identity as members of a religious community, and explore alterity in and through their work, without jeopardizing the safety and well-being of my students.

In the role of a media educator who is dealing with a sensitive issue such as religious literacy and encouraging students to enact practices of resistance, I have a set of personal guidelines in place when I interact with my students. Though the review board ensures that a researcher follows the ethical code of conduct, when we think about such an immersive experience, we realize that immersion can never be structured or controlled by predetermined guidelines. Each media educator must draft a rulebook to help him/her navigate smoothly through classroom experiences which might threaten the safety of their students. Personally, I follow these three rules: 
1. Involve parents and community members in various media education exercises either for assistance or for participation

2. Conduct training sessions at schools sensitizing other teachers towards the social issues being dealt with

3. Ensure that students engage in both analysis and practice to equip them with the necessary competencies to continue working in that area after the media educator withdraws from the setting.

\section{CONCLUSION}

Through this paper I wish to draw attention to the fact that reflexive research in critical media literacy can yield new conceptual frameworks for analysis based on the empirical insights derived from the everyday interactions and experiences of media educators. This involves a theoretical explication of how CML curriculum requires a revised analysis of media ecologies of young students that are deeply inflected by students' "contextual knowledge and embeddedness in diverse non-mediated communities" (Banaji, 2015) such as religion, education, social class, gender and so on.

Let us take the example of one such CML sessions aimed at creating alternate narratives. My students and I were making a movie addressing the problem of microaggression to demonstrate how power is constitutive and each individual reifies the Hindu-Muslim conflict by engaging in everyday acts of discrimination at the village level. The aim was to allow students to reflect on how their classmates in the village school enact and perpetuate violence towards others by using religious slurs such as "O Mommin" (Oh Muslim), "Oh Topi" (referring to the prayer caps that Muslims wear) "O Chaddi" (Referring to the right wing ideology of Hindu nationalism) and so on.

For filming a particular scene, a team of students decided to visit a community space which is generally inhabited by the Muslims. I was a little apprehensive because there is a huge mosque in that part of the village and I wasn't sure if photography was permitted in and around the mosque grounds. Also, I wasn't ready to subject my Hindu students to hostile and suspecting stares when they used a camera in front of the Muslim households- recording everyday activities in those narrow lanes.

My Muslim students, however, came to my rescue and offered to be our guide. I distinctly remember Irfan taking us to his house, introducing me to his grandmother and saying in a reassuring tone, "Ma'am, this is my area, my house. . . We can use the camera here. I have taken the required permissions from my neighbors." Towards the end of the production activity, his grandmother also served all the students with light refreshments and they "ate together."

This anecdote explains why critical media literacy exercises must be framed based on an analysis of their everyday experiences and must be responsive to the everyday contradictions students face in their immediate environments. In understanding contemporary students' lives, we need to move beyond technology (Buckingham, 2007). According to Banaji (2015), “. . . enabling environments are likely to emerge only by building on students' ingenuity and insight, designing intelligent 
media, and through an educational curriculum that encourages social questioning, in non-digital or low-tech spaces for students."

An analysis of media cannot take place without examining diverse facets of a student's identity including religion, economics, education, culture and community while at the same time dovetailing into practices which have real consequences for the students in their communities. Critical media literacy provides the required resources such as technical competencies to create, circulate and debate new ideas challenging the status quo, material means to produce forms of resistance through critical questioning of the synthetic history, and a site for gaining and aligning public support for new realities. We need to acknowledge that critical media literacy has the potential to alter the collective capillaries of public life through which a dominant ideology is reified and reinforced.

\section{REFERENCES}

Ahmed, S. (2010). The role of the media during communal riots in India: A study of the 1984 Sikh riots and the 2002 Gujarat riots. Media Asia, 37 (2), 103-111.

Aleaz, B. (2005). Madrasa education, state and community consciousness. Economic and Political Weekly, 40 (2), 86-91.

Bazalgette, C. (2009). Impacts of Moving Image Education. Glasgow: Scottish Screen. Retrieved on March 10, 2017 from http://www.scottishscreen.com/images/documents/mie_research_summary.pdf

Banaji, S. (2015). Behind the high-tech fetish: Students, work and media use across classes in India. The International Communication Gazette, 77 (6), 577-599.

Bandyopadhyay, D. (2002). Madarasa education and the condition of Indian Muslims. Economic and Politically Weekly, 37 (16), 61-64.

Banaji, S. (2006). Reading Bollywood: The Young Audience and Hindi Film. Basingstoke: Palgrave Macmillan.

Bennet, W. L. (2008). Changing citizenship in the digital age. In W. L. Bennet (Ed.), Civic Life Online: Learning How Digital Media Can Engage Youth. Cambridge, MA: MIT Press. (1-24)

Berger, P., \& Luckman, T. (1966). The social construction of reality. London: Penguin Books.

Berman, J. (2003). The Labouring Poor in India: Patterns of Exploitation, Subordination and Exclusion. Delhi: Oxford University Press.

Bhatia, K. (2017). Understanding the role of media education in promoting religious literacy: A critical pedagogy for primary school students in rural India. Media Education Research Journal, 7 (2), 11-28.

Bhatia, K., \& Pathak-Shelat, M. (2017). Media literacy as a pathway to religious literacy in pluralistic democracies: Designing a critical media education pedagogy for primary school students in India. Interaction: Studies in Communication and Culture, 8 (2), 189-209.

Buckingham, D. (1995). Making Media: Practical Production in Media Education. London: The English and Media Center. 
Buckingham, D. (2003). Media Education: Literacy, Learning and Contemporary Culture. Cambridge: Polity Press.

Buckingham, D., \& Bragg, S. (2004). Young People, Sex and the Media. Basingstoke: Palgrave Macmillan.

Conroy, J. (2004). Betwixt and Between: The Liminal Imagination, Education and Democracy. New York: Peter Lang.

Conroy, J. \& Ruyter, D. (2009). Contest, contradiction, and security: The moral possibilities of liminal education. Journal of Educational Change, 10 (1), 1-12.

Cooker-Sather, A. (2010). Students as learners and teachers: Taking responsibility, transforming education, and redefining authority. Curriculum Inquiry, 40 (4), 555-575.

Cook-Sather, A, \& Alter, Z. (2011) What is and what can be: How a liminal position can change learning and teaching in higher education. Anthropology \& Education Quarterly 42:1, 37-53.

Fahimudin, A. (2009). Rationale of modernization of madrasa education in India. In N. Hasnaun (Ed.) Beyond textual Islam. New Delhi: Serials. (10-28)

Farouqui, A. (Ed.). (2009). Muslims and Media Images: News versus Views. New Delhi: Oxford University Press.

Foucault, M. (1997). Discipline and Punish: The Birth of the Prison. (A. Sheridan, Trans.) New York: Random House.

Frøystad, K. (2005). Blended Boundaries: Caste, Class, and Shifting Faces of 'Hinduness' in a North Indian City. New Delhi: Oxford University Press.

Gennep, A. (1960). The Rites of Passage. (M. Vizedon, \& G. Caffee, Trans.) London: Routledge.

Giroux, H. A. (1992). Border Crossings: Cultural Workers and the Politics Of Education. New York: Routledge.

Goodman, S. (2003). Teaching Youth Media: A Critical Guide to Literacy, Video Production and Social Change. New York: Teacher College Press.

Harvey, D. (2003). The fetish of technology: Causes and consequences. Macalester International, 13 (7), 3-30.

Haydari, N., \& Kara, M. (2015). A collaboratıve media production project on human rights: bridging everyday and media education. Innovations in education and teaching international students, 52 (4), 383-392.

Hoechsmann, M., \& Poyntz, S. (2012). Media Literacies: A Critical Introduction. Oxford: Blackwell Publishing .

Hurlock, D. et. al. (2008). Falls the shadow and the light: liminality and natality in social work field education. Teaching in Higher Education, 13 (3), 291-301.

Irving, A. \& Young, T. (2004). Perpetual liminality: Re-readings of subjectivity and diversity in clinical social work classrooms. Smith College Studies in Social Work, 74 (2), 213-227.

Jain, A. (2010). Beaming it live: 24-hour television news, the spectator and the spectacle of the 2002 Gujarat Carnage. South Asian Popular Culture, 8 (2), 163 179.

Jayal, N. G. (2001). Democracy and the State: Welfare, Secularism and Development in Contemporary India. New Delhi: Oxford University Press. 
Johnson, K. (2001). Media and social change: The modernising influences of television in rural India. Media, Culture and Society, 23 (2), 147-169.

Karim, K. H. (2002). Making sense of the "Islamic peril": Journalism as cultural practice. In B. Zelizer, \& S. Allan (Eds.) Journalism after September 11. New York: Routledge. (101-116).

Khan, N. (2014). Media and youth: Radio listening and television watching patterns of Meitei Pangal students in Manipur. Academicia, 4 (4), 43-52.

Kirmani, N. (2008). Competing constructions of "Muslim-ness" in the south Delhi neighborhood of Zakir Nagar. Journal of Muslim Minority Affairs, 28 (3), 355370 .

Kononova, A., Alhabash, S., \& Cropp, F. (2011). The role of media in the process of socialization to American politics among international students. International Communication Gazette, 73 (4), 302-321.

Kumar, K. J. (2010). Representations of Islam in the mass media: An analysis from a reception studies perspective. In J. Raja (Ed.) Representations of Religion in the Mass Media. New Delhi: I.S.P.C.K.

Land, R., Rattray, J. \&Vivian, P. (2014). Learning in the luminal space: A semiotic approach to threshold concepts. High Edu, 67(2), 199-217.

Lankshear, C. (1997). Changing Literacies, Changing Education. New York: Open University Press.

Lynn,B., Kawalilak, C., \& Patterson, P. (2008). Betwixt and between: Academic women in transition. Canadian Journal of Higher Education, 38 (2), 95-115.

McLaren, P. (1995). Critical pedagogy and predatory culture: Oppositional politics in a postmodern era. New York: Routledge.

Meyer, J., \& Land, R. (2006). Overcoming Barriers to Student Understanding: Threshold Concepts and Troublesome Knowledge. London: Routledge.

Nussbaum, M. (2008). The Clash Within: Democracy, Religious Violence, and India's Future. Cambridge: Harvard University Press.

Pratt, M. (1992). Arts of the contact zone. Modern Language Association, 5 (8), 33-40.

Rajagopal, A. (2001). Politics after Television: Hindu Nationalism and the Reshaping of the Public In India. Cambridge: Cambridge University Press.

Ranieri, M., \& Fabbro, F. (2016). Questioning discrimination through critical media literacy. Findings from seven European countries. European Educational Research Journal, 15 (4), 462-479.

Rantala, L. (2009). In search of third spaces in media education: An ethnographic study from fifth graders' media workshop. Pedagogy, Culture and Society, 17, 385399.

Schwartzman, L. (2010). Transcending disciplinary boundaries: A proposed theoretical foundation for threshold concepts. In J. H. F. Meyer, R. Land, \& C. Baillie (Eds.) Threshold concepts and transformational learning. Rotterdam: Sense Publishing. (21-44).

Sonwalkar, P. (2006). Shooting the messenger? Political violence, Gujarat 2002 and the Indian news media. In B. Cole (Ed.) Conflict, Terrorism, and the Media in Asia. New York: Routledge. 
Sparkes, A. (2000). Autoethnography and the narratives of self: Reflections on criteria in action. Sociology of Sport Journal, 17, 21-43.

Sikand, Y. (2004). Islam, Caste, and Dalit-Muslim Relations in India. Delhi: Global Media Publications.

Sud, N. (2012). Liberalization, Hindu Nationalism and the State: A Biography of Gujarat. New Delhi: Oxford University Press.

Sud, N. (2009). Secularism and the Gujarat state: 1960-2005. Modern Asian Studies, 42 (6), 1251-1281.

Tempest, S., \& Starkey, K. (2004). The effects of liminality on individual and organizational learning. Organization Studies, 25 (4), 507-527.

Turner, V. (1964). Betwixt and between: The liminal period in rites de passage. Symposium on New Approaches to the Study of Religion, (pp. 4-20).

Turner, V. (1983). Liminal to liminoid, in play, flow, and ritual: An essay in comparative symbology. In J. Harris, \& R. Park (Eds.), Play, Games and Sports in Cultural Contexts. Illinois: Human Kinetics Publishers. (123-163).

Turner, V. (1966). The Ritual Process: Structure and Anti-Structure. New York: Cornell University Press.

Valsamidis, P. (2016). Representing "Us"- representing "Them": Visualizing racism in Greek primary school films. In J. Singh, P. Kerr, \& E. Hamburger (Eds.) Media and Information Literacy: Reinforcing Human Rights, Countering Radicalization and Extremism. Paris: UNESCO. (213-222).

Velde, J. (2012). From Liminal to Liminoid: Eminem's Trickstering. Bergen: University of Bergen.

Willet, R. (2008). Consumer citizens online: Structure, agency, and gender in online participation. In D. Buckingham (Ed.) Youth, Identity and Digital Media. Cambridge: MIT Press. (49-69).

Yagnik, A., \& Sheth, S. (2005). The Shaping of Modern Gujarat: Plurality, Hindutva and Beyond. New Delhi: Penguin India. 